ISSN 2078-6441. Вісник Львівського університету. Серія географічна. 2013. Випуск 42. С. 11-21. Visnyk of the Lviv University. Series Geography. 2013. Issue 42. P. 11-21.

$551.8: 631.472(477.82+477.43 / .44)$

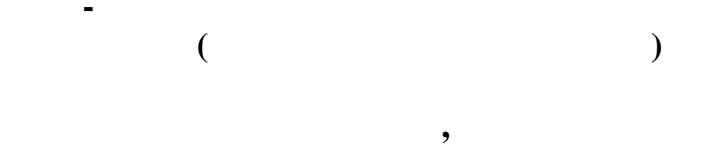

ввівський н ціон льний університет імені в н вул. . орошенк , 41, 79000, м. ввів, кр їн

озріз оршів-опорний - один із н йліпше вивчених і н йповніших розрізів перигляці льної лесово-грунтової серії олино- оділля. г льн потужність лесово-грунтової серії тут ст новить близько 30 м. е стр тотип коршівського викопного грунтового комплексу і луцького викопного грунту. ут уперше для олино- оділля виділено псевдоморфози по полігон льно-жильних льод х кількох ет пів середньоплейстоценового п леокріогенезу.

ведено дет льний опис розрізу, т кож результ ти інженерно-геологічного вивчення порід усіх виділених лесових і п леогрунтових горизонтів. 'ясов но індивіду льність вл стивостей виділених стр тигр фічних горизонтів і їхню з лежність від п леогеогр фічних умов ос дон гром дження.

лючові слов : леси, похов ні грунти, п леогеогр фічні умови, інженерно-геологічні вл стивості, прос дочність, олинськ височин .

порний розріз оршів розт шов ний з 18 км н південний з хід від м. уцьк, біля c. овокоршів, у великому к р'єрі з видобутку сировини для цегельних з водів уцьк еоморфологічно це сл бкорозчленов н вододільн лесов рівнин, обмежен 3 півночі прохідною долиною уг - орногузк . е один із н йповніше вивчених розрізів лесово-грунтової серії олино- оділля. ін є стр тотипом коршівського викопного грунтового комплексу, луцького грунту, дет льно прод тов ний [4]. озріз неоднор зово демонструв ли уч сник м міжн родних конференцій і семін рів. ут уперше опис но декільк генер цій псевдоморфоз по полігон льно-жильних льод х середньоплейстоценового кріогенезу [2]. уже в жливо, що розріз і досі доступний для вивчення н всю потужність.

ведемо дет льний опис порід розрізу оршів-опорний (див. рисунок).

уч сний чорнозем (1) ${ }^{1}$. формов ний н лес х і вкр й порушелибин , м ний к р'єрними робот ми. є добре диференційов ний профіль.

умусовий ( ) горизонт скл дений грудкув тими супіск ми темно-сірого кольору потужністю 0,5 м. ерехід поступовий.

люві льний ( $к$ рбон., кротов.) горизонт потужністю 0,5 м скл дений супіск ми сірув то-коричневими, що суцільно перероблені кротовин ми т червоточин ми. ерехід з кольором, ясний.

1 ут і д лі номер горизонту чи підгоризонту відповід $є$ стр тигр фічній шк лі $[1,3]$.

(C) огуцький ., олошин ., 2013 

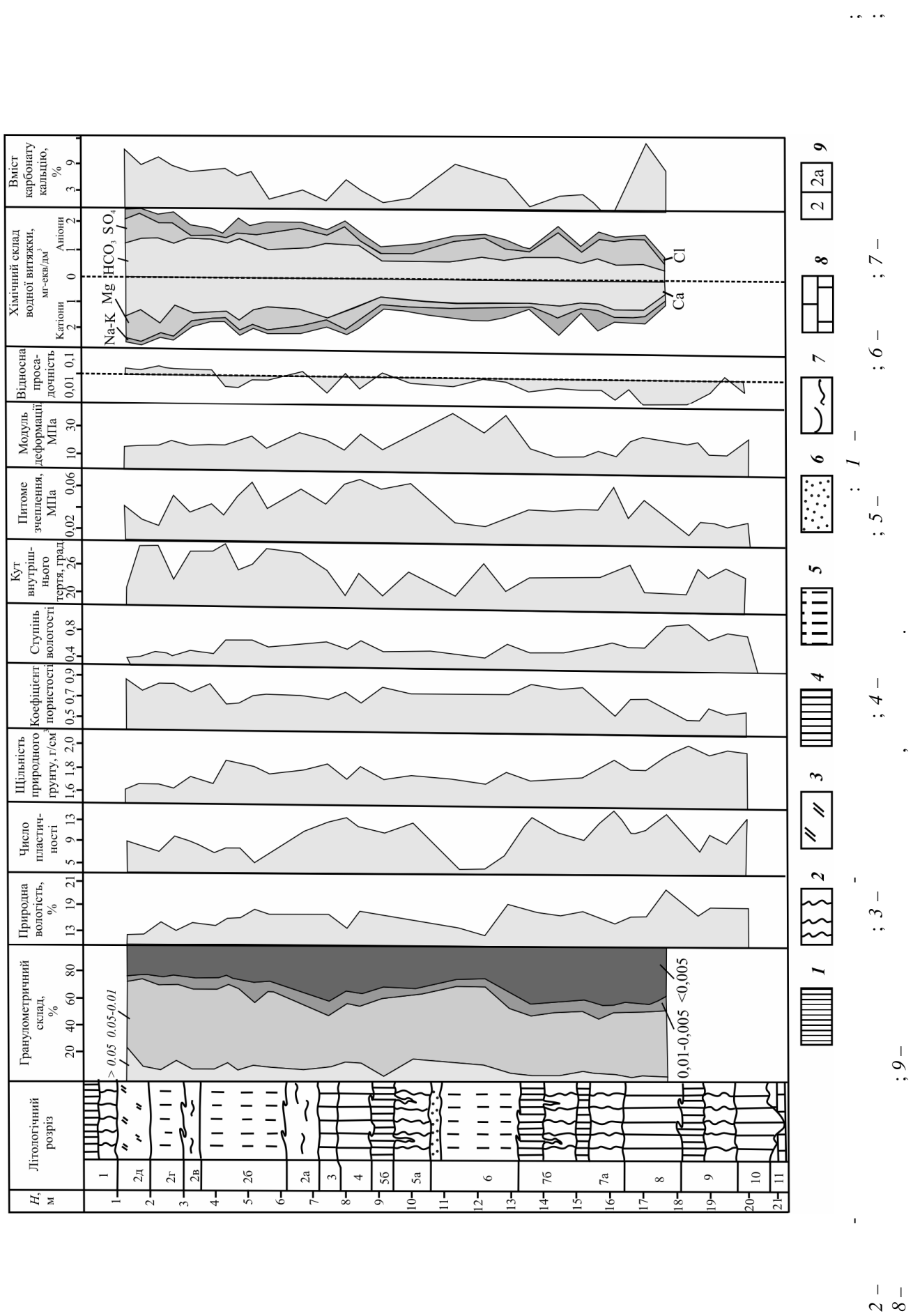
ерхній горизонт верхньоплейстоценових лесів (2). морфологічними особливостями розділений н п'ять підгоризонтів.

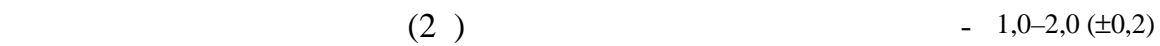
сірими, оглеєними, які бурхливо з кип ють з $\mathrm{HCl}, \mathrm{н}$ сичені к рбон тними конкреціями до 4,0 см у ді метрі й к рбон тними трубочк ми до 1,0 мм у ді метрі. ш рі нем ло трубч стих $з$ лізистих новоутворень типу кілець ізег нг . ід нижнього конт кту ш ру відходять у підстильні породи вузькі (перші с нтиметри) тріщини, інкрустов ні 3, зі смуг ми бурого оз лізнення по конт кт х. либин тріщин - 0,5-1,0 м, вони тр пляються через кожні 1,2-1,6 м. ерехід поступовий.

ерхній підгоризонт верхнього горизонту верхньоплейстоцено- 2,0-3,0 $( \pm 0,2)$ вих лесів (2г). редст влений супіск ми п левими, однорідними, м кропористими, вертик льно тріщинув тими, що н сичені к рбон тними трубочк ми до 1,0 мм у ді метрі. е н йтиповіший лес верхнього плейстоцену. ерехід ясний. о нижньому язикув тому конт кту є смуги бурого оз лізнення, іноді потужний (декільк с нтиметрів) ортз нд.

івненський підгоризонт (2в). е ш р інтенсивно порушених і 3,0-3,6 $( \pm 0,2)$ оглеєних супісків м кропористих, що інтенсивно з кип ють з $\mathrm{HCl}$. олір ш ру неоднорідний, що виявляє його скл дну язикув толінзоподібну будову. ерев ж ють голубув то-сірі, бурі (очевидно, 3 вдяки оз лізненню) i жовтув то-коричневі тони. отужність окремих язиків досяг є м ксим льно 0,1 м, їхній н хил з д внім рельєфом ст новить 25-30 . о верхньому і нижньому конт кт х добре вир жені смуги бурого оз лізнення, ділянк ми й оглеєння.

ижній підгоризонт верхнього горизонту верхньоплейстоцено- 3,6-6,2 (₫0,2) вих лесів (2б). е головно суглинисті леси сірого і світлокоричневого кольору, гумусов ні, 3 плям ми гумусу темного кольору м йже до 10,0 см у ді метрі. ороди інтенсивно оз лізнені, містять б г то плям оглеєння. ілянк ми тут простежується ш рув тість, виділен смуг ми бурого оз лізнення.

ідгоризонт н ддубнівської соліфлюкцї (2 ). кл дений сірими, 6,2-7,2 коричнюв то-сірими оглеєними суглинк ми 3 включеннями у вигляді лінз і “пирогів” голубув то-сірого м тері лу дубнівського викопного грунту, що з ляг є нижче. ключення до 0,2 м і більше м ють дуже скл дну конфігур цію зі смуг ми бурого оз лізнення по периметр х, які ч сто переходять в ортз нди потужністю до 2 см.

убнівський викопний грунт (3). обре вир жений по всьому розрізу, хоч ділянк ми інтенсивно порушений і “розтягнутий” соліфлюкційними процес ми. редст влений щільними (проте м кропористими), в жкими супіск ми голубув то-сірого кольору, які в основній м сі не 3 кип ють 3 1, оглеєними. упіски інтенсивно плік тивно деформов ні, про що свідч ть скл днохвилясті смуги бурого оз лізнення. р містить велику кількість з лізистом нг нових новоутворень перев жно бурого кольору до 5,0 мм 
у ді метрі. горизонті нем ло включень (лінзи, гнізд потужністю до 2,0 см) жовтув то-сірих супісків, які переповнені к рбон тними трубочк ми і дутик ми. о периметр х включень, т кож по верхньому і нижньому конт кт х ш ру є потужні (до 2,0 см) смуги бурого оз лізнення, які ділянк ми переходять в ортз нди. пород х підвищений вміст глинистої фр кції (близько $29 \%$ ), зрост є кількість гумусу, молекулярні співвідношення $\mathrm{SiO}_{2}: \mathrm{Fe}_{2} \mathrm{O}_{3}$ дешо зменшуються. нижній ч стині дубнівського грунту інколи тр пляються скл днодеформов ні лінзи темно-сірого гумусов ного м тері лу потужністю до 0,2-0,3 м.

ижній горизонт верхньоплейстоценових лесів (4). кл дений суглинк ми червонув тими у верхній половині ш ру (підгоризонт 46) і жовтув то-бурими у нижній (підгоризонт 4 ). углинки середньої щільності, к рбон тні, у нижній половині ш ру з чіткою посткріогенною неповносітч стою текстурою (висот сітки 0,3-0,5 см, ширин - 1,0-3,0 см), як добре виділен плівк ми бурого оз лізнення. ерехід 3 появою язиків темно-сірих суглинків 3 м тері лу горизонту горохівського викопного грунтового комплексу, що з ляг є нижче.

орохівський викопний грунтовий комплекс (5). є добре диференційов ний профіль, у якому виділяють т кі основні генетичні горизонти.

умусовий ( ) горизонт потужністю 0,4-0,5 м скл дений легкими суглинк ми темно-сірого кольору 3 коричневим відтінком, щільними, безструктурними, що з кип ють 31 в верхніх $0,1 \mathrm{M}$ горизонту спостеріг ємо чітку неповносітч сту посткріогенну текстуру (висот сітки - до 0,5 см, ширин - до 3,0 см), як виділен плівк ми бурого оз лізнення. о підошві суглинків проходить чітк смуг бурого оз лізнення потужністю до $1,0 \mathrm{~cm}$. нижній половині умусового горизонту $є$ інтенсивн біогенн переробленість (червоточини, кротовини). ерехід поступовий, 3 появою чіткої білястої присипки. рунтов м с у шліфі 3 умусового горизонту м є в прохідному світлі сірув то-коричневе з $б$ рвлення, грегов н . грег ти першого і другого порядків м ють розміри до 0,2 мм. онкодисперсн речовин глинисто- умусов, ізотропн . зн к її переміщення в горизонті нем .

оризонт / $l$ потужністю 0,15 м скл дений супіск ми сірими 3 коричнюв тим відтінком, пилув тими, з білястою присипкою, 31 не $з$ кип ють. упіски безструктурні, з великою кількістю з лізистом нг нових новоутворень, інтенсивно біогенно перероблені. ерехід язикув тий: від нижнього конт кту через кожні 0,7-1,5 м відходять у породи, що з ляг ють нижче, язики (“косми”) глибиною до 1,0 м i більше. повнені косми м тері лом горизонту . p ктер н повнюв ч субвертик льний.

оризонт $l$ скл дений світло-коричневими, місцями світлосірими (білястими) супіск ми, пухкими, неясноплитч стими (товщин плиток не перевищує 3,0 мм). ш рі нем ло кротовин 
і червоточин з н повнюв чем із м тері лу горизонту . ля ш ру х р ктерн велик кількість з лізисто-м нг нових новоутворень до 3,0 мм у ді метрі, ч сто с жистих. ижній конт кт ясний, з зміною щільності т кольору порід тощо. отужність горизонту - 0,1 м, в д вніх мікроз п дин х збільшується до 0,5 м і більше. оризонт головно пов'яз ний із з п дин ми д внього рельєфу. оризонт безк рбон тний, відрізняється різким зменшенням вмісту гумусу.

оризонт ${ }_{m}$ виділений у розріз х досить чітко з вдяки великій щільності порід і яскр во-коричневому кольору. кл дений супіск ми, ч сто піщ нистими, які переходять до основи горизонту в ш рув ті кв рцові різнозернисті піски. ут чітк комірч ст текстур, ді метр комірок досяг є 10,0 мм. упіски інтенсивно біогенно перероблені, $3 \quad 1$ не вз ємодіють.

отужність горизонту ${ }_{m t}-0,8$ м, ч сто більше. мікроморфологічними д ними у прохідному світлі грунтов м с м є яскр вобуре з б рвлення, скл д ється зі щільно укл дених грег тів першого порядку, які розділені тріщин ми-пор ми. о стінк х пор шк р лупув ті глинисті кут ни ілювіюв ння. линисто-з лізист пл зм оптично орієнтов н, дуже оз лізнен, б г то пл стівцеподібних відокремлених гідроокислів 3 ліз, їхніх неоформлених скупчень, модулів. глибиною до перев жних у скелеті пилув тих ч стинок дод ються обк т ні піщ ні зерн . ут ни ілювіюв ння скл дні - глинисті кут ни переш ров ні із з лізистими.

ороди безк рбон тні, з низьким вмістом гумусу. ижній конт кт ясний, скл днохвилястий. ін 3 фіксов ний чіткою смугою бурого оз лізнення, як місцями переходить в ортз нди до 1,0 см потужністю.

ерхній горизонт середньоплейстоценових лесів (6). орфологічно неоднорідний. озпочин ється він піск ми потужністю 0,2-0,3 м, які в основній м сі тонко- і середньозернисті. ише в окремих тонких (до 5,0 см) лінз х виявлено крупно- і грубозернисті піски. ерев жний х р ктер ш рув тості пісків горизонт льноХвилястий. ш рув тістю спостеріг ємо плівки бурого оз лізнення, н йінтенсивніше оз лізнення приурочене до верхнього і нижнього конт ктів ш ру. піск х зн йдено як окремі кротовини до $15,0 \mathrm{~cm}$ у ді метрі, т к і їхні великі скупчення. повнюв чем кротовин є м тері лз горизонту горохівського комплексу.

ижче 3 ляг ють леси потужністю до 2,2 м. они супіш ні, к рбон тні, п леві з зеленкув тим відтінком, м кропористі, місцями ш рув ті. рув тість виділен смуг ми бурого оз лізнення, головно горизонт льними. ш рі нем ло плям оз лізнення й оглеєння до 5,0 cм у ді метрі, т кож з лізисто-м нг нових прим зок. иявлено т кож к рбон тні дутики ді метром до 3,0 см т псевдоміцелій. нижній ч стині ш ру з ляг ють суглинки щільні, м кропористі, к рбон тні, сірі з зеленкув тим відтінком, місцями 3 добре вир женою неповносітч стою посткріогенною текстурою. исот сітки - до 1,5 см, ширин - до 3,0 см. іля підошви ш ру 
є лінзи і гриви гумусов них суглинків з горизонту другої ф зи коршівського грунтоутворення потужністю до $10,0 \mathrm{~cm}$. ерехід поступовий.

оршівський викопний грунтовий комплекс (7). редст влений грунт ми двох ф з грунтоутворення. собливо яскр во вир жений грунт другої ф зи (верхній) - потужний повнопрофільний чорноземоподібний грунт. грунті першої ф зи коршівського грунтоутворення (нижньому) генетичний профіль виявлено не з вжди. нколи це потужний горизонт грегув ння нижче горизонту другої ф зи коршівського викопного грунтового комплексу.

рунт першої ф зи коршівського комплексу (нижній, підгоризонт 7 ) м є т ку будову.

умусовий ( ) горизонт потужністю 0,3 м предст влений суглинк ми середніми до в жких, грудкув тими, місцями безструктурними. углинки сірого кольору, з коричнюв тим відтінком. $\mathrm{HCl}$ не вз ємодіють.

люві льний ( ) горизонт потужністю 1,1 м, інколи більше, скл дений суглинк ми світло-коричневими, з червонув тим відтінком, грудкув тими, дуже щільними, з комірч стою текстурою (ді метр комірок - до $0,5 \mathrm{~cm})$. $\mathrm{HCl}$ не вз ємодіють. ижній конт кт ясний, 3 зміною кольору.

рунт другої ф зи коршівського грунтоутворення (верхній, підгоризонт 7б) т кож м є добре розвинений генетичний профіль, у якому виділяють т кі горизонти.

умусовий ( ) горизонт потужністю 0,7 м скл дений суглинк ми коричневими, середніми до в жких, безструктурними, безк рбон тними, щільними, однорідними. углинки інтенсивно біогенно перероблені. ижній конт кт язикув тий: язики глибиною до 1,0 м і шириною (зверху) до 0,2 м виявлено через кожні $0,5-1,2$ м.

люві льний ( ) горизонт потужністю до 0,5 м утворений п левими і яскр во-жовтими суглинк ми, однорідними, які не з кип ють з $\mathrm{HCl}$. углинки переповнені з лізисто-м нг новими новоутвореннями, для них х р ктерн інтенсивн біогенн переробленість. ут б г то кротовин до 10,0 см у ді метрі, т кож велик кількість червоточин. повнюв чем кротовин і червоточин слугує м тері л горизонту цього грунту. ерехід 3 зміною кольору і щільності порід, ясний.

ижній горизонт середньоплейстоценових лесів (8). кл дений у верхній ч стині голубув то-сірими (сизими) суглинк ми з неповносітч стою посткріогенною текстурою, іноді з фіксов ною плівк ми бурого оз лізнення. углинки легкі, пилув ті, щільні, містять к рбон тні конкреції (дутики) до 5,0 см у ді метрі. углинки інтенсивно просякнуті гідрооксид ми з ліз, інтенсивність оз лізнення з глибиною зменшується.

поверхні ш ру розпочин ються численні літогенні тріщини глибиною до 0,5 м, нижній конт кт скл днохвилястий, виділений смуг ми бурого оз лізнення.

\section{$13,3-16,5$}


нижній ч стині ш ру з фіксов но соліфлюкційну п чку, як головно скл д ється з:

) супісків білястих, н сичених з лізисто-м нг новими новоутвореннями. обре видно, що гриви, скл дені цими супіск ми, розпочин ються з горизонту луцького викопного грунту, що з ляг $€$ нижче. отужність грив і лінз не перевищує 0,1 м;

б) суглинків голубув то-сірих, неповносітч стих, інтенсивно оз лізнених i через це коричнюв то з б рвлених. отужність суглинків в окремих язик х і лінз х, т кож “пирог х” досяг є 0,5 м.

окремих ділянк х голубув то-сірі суглинки ст новлять основну ч стину соліфлюкційної п чки;

в) суглинків коричнюв то-сірих, безструктурних, інколи з червонув тим відтінком, які містять велику кількість з лізистом нг нових новоутворень до 3,0 мм у ді метрі й ул мки вугілля до 1,0 см у поперечнику.

г льною особливістю соліфлюкційної п чки $є$ інтенсивн оглеєність, оз лізненість, т кож систем “сколів" (мікроскидів) 3 мплітудою до 0,3 м, зрідк більше. ороди ш ру з $\mathrm{HCl}$ не в3 ємодіють, проте в них виявлено великі (до 5,0-7,0 см) щільні к рбон тні конкреції. ерехід ясний, фіксов ний смугою бурого оз лізнення потужністю до 1,0 см.

пис ну соліфлюкційну п чку н зив ємо н длуцькою.

уцький викопний грунт (9) (грунтовий комплекс ?). ідповід є 18,2-19,8 ( $\pm 0,3)$ верхній ч стині лихвинської міжльодовикової епохи. ін інтенсивно порушений соліфлюкційними процес ми.

умусовий ( ) горизонт виявлено здебільшого у вигляді окремих включень потужністю 0,3 м у соліфлюкційних п чк х. кл дений суглинк ми сірув то-коричневими, червонув тими, безструктурними, середньої щільності, які не 3 кип ють $3 \mathrm{HCl}$. ш рі б г то з лізисто-м нг нових новоутворень до 3,0 мм у ді метрі, т кож ул мків вугілля до 1,0 см у поперечнику.

люві льний ( ) горизонт потужністю 0,2 м скл дений плитч стими супіск ми, світло-сірими з коричнюв тим відтінком, пухкими, безк рбон тними, що н сичені з лізисто-м нг новими новоутвореннями чорного кольору до 3,0 мм у ді метрі. ш рі б г то ул мків вугілля до 1,5 см у поперечнику. о тріщин х і текстурних окремостях м тері л горизонту проник $є$ у підстильний горизонт $\mathrm{H}$ глибину до 0,5 м. ерехід ясний.

люві льний ( ') горизонт потужністю 0,5 м утворений суглинк ми щільними, горіхув тими, інколи комірч стими, червонув токоричневого кольору, 3 білястою присипкою по тріщин х $\mathrm{i}$ структурних окремостях. $\mathrm{HCl}$ суглинки не вз ємодіють, містять велику кількість з лізисто-м нг нових новоутворень. ут т кож б г то ул мків вугілля до $1,5 \mathrm{~cm}$ у поперечнику, виявлено плями оглеєння до 2,0 см у ді метрі. ерехід ясний.

люві льний (") горизонт потужністю $0,3-0,5$ м скл дений суглинк ми, що відрізняються від суглинків горизонту' меншою 
щільністю порід. ут менш інтенсивність оз лізнення, нем білястої присипки. ерехід поступовий, з зміною кольору.

ерхній горизонт нижньоплейстоценових лесів (10). кл дений суглинк ми легкими, пилув тими, середньої щільності, інколи м кропористими, жовтого кольору, 3 коричневим відтінком. углинки однорідні, з $\mathrm{HCl}$ не вз ємодіють. ижній конт кт різкий, ерозійний.

орінні породи предст влені інтенсивно звітрілими верхньокрейдовими в пняк ми і мергелями. хня поверхня дуже нерівн , із 3 глибленнями до 5,0 м і більше. 3 глибленнях н поверхні крейди

$19,8-21,0$

(інколи до 22,0

і більше)

$21,0-22,0$

(розкрито) $€$ і м ксим льні потужності лесово-грунтової серії.

езульт ти л бор торних досліджень грунтів ${ }^{2}$ окремих лесових, п леогрунтових т п леокріогенних горизонтів, виділених у лесово-грунтовій товщі опорного розрізу оршів, свідч ть про суттєві відмінності між ними як з морфологічними особливостями, т к і з скл дом, фізико-мех нічними т фізико-хімічними вл стивостями. иявлено т кож певні з кономірності їхніх змін з глибиною (див. рисунок).

ерхній горизонт верхньоплейстоценових лесів морфологічно неоднорідний. розрізі оршів-опорний вивчено інженерно-геологічні вл стивості п'яти підгоризонтів $^{3}:$ кр силівського (2д), верхнього (2г), рівненського (2в), нижнього (2б) т підгоризонту соліфлюкції (2). рунти цього горизонту з гр нулометричним скл дом м ють типовий лесовий вигляд. йбільше в них пилув тих ч стинок. хній вміст пересічно ст новить $57 \%$. томість кількість цих ч стинок з окремими підгоризонт ми дещо змінн . кр силівському т нижньому підгоризонт х вон ст новить 54,1-55,1\%, у верхньому і рівненському підгоризонт х перевищує $59 \%$. міст піщ них ч стинок у меж х горизонту змінюється від $17,4 \%$ у грунт х кр силівського підгоризонту до 9,4 \% у рівненському підгоризонті. ількість глинистої фр кції - від 22,4 до 27,1 \%.

йбільш глинистість прит м нн грунт м підгоризонтів соліфлюкції т рівненського. грунт х соліфлюкційного підгоризонту, які формув лись у холодних, проте вологих умов х, вміст пилув тої фр кції зменшується до 43,6 \%, н томість кількість глинистих ч стинок зрост є до $35,2 \%$.

ерхній горизонт середньоплейстоценових лесів пересічно вміщує 12,7 \% піщ них ч стинок, 57,5 - пилув тих, 24,4\% глинистих. гр нулометричним скл дом леси цього горизонту м йже ідентичні лес м верхнього горизонту верхньоплейстоценових лесів. рунти нижнього горизонту середньоплейстоценових лесів більш глинисті. ередне зн чення вмісту піш них ч стинок ст новить 4,0\%, пилув тих - 49,2, глинистих $-38,5 \%$. ідгоризонти соліфлюкції т оглеєння, які входять до скл ду н зв них горизонтів, т кож м ють підвищену глинистість.

икопні грунти і грунтові комплекси з гр нулометричним скл дом суттєво відмінні від горизонтів лесів. інім льний вміст пилув тих ч стинок $(39,3 \%)$ т н йбільший глинистих $(41,1 \%) є$ у пород х дубнівського викопного грунту. рунти горохівського

2 інженерній геології під грунт ми розуміють усі породи, які є середовищем бо основою споруд.

3 остий, н ймолодший підгоризонт верхнього горизонту верхньоплейстоценових лесів лес (2e) - інтенсивно перетворений суч сним грунтоутворенням, через що у цьому розрізі ми його не випробовув ли. 
т коршівського викопних комплексів з гр нулометричним скл дом відрізняються як від лесових горизонтів, т к і від дубнівського викопного грунту. міст піщ них ч стинок у горохівському т коршівському комплекс х ст новить, відповідно, 10,2 і $5,6 \%$, пилув тих $-52,8$ і 47,5 \%, глинистих - 31,9 і 37,6 \%.

бсолютні зн чення природної вологості грунтів опорного розрізу оршів змінюються від 13 до $23 \%$. грунт х верхнього горизонту верхньоплейстоценових лесів вон поступово зрост є, досяг ючи до підошви ш ру 17-18\%. ижче у дубнівському викопному грунті, нижньому горизонті верхньоплейстоценових лесів т горохівському викопному грунтовому комплексі вон м йже ст л і ст новить 17-18\%. верхньому горизонті середньоплейстоценових лесів вологість знову зменшується до 12-13\%.

нижній ч стині цього горизонту (н дкоршівськ соліфлюкційн п чК ) вон зрост є до $19 \%$ і пр ктично не змінюється в грунт х коршівського викопного грунтового комплексу, луцького викопного грунту і верхнього горизонту нижньоплейстоценових лесів. д луцьким викопним грунтом (н длуцьк соліфлюкційн п чк ) з фіксов но зрост ння вологості до $23 \%$.

л стичність грунтів тісно корелює 3 глинистістю окремих стр тигр фічних елементів. еси верхніх горизонтів верхнього т середнього плейстоцену м ють низькі зн чення числ пл стичності, що змінюються від 4 до $9 . \quad$ лес х нижніх горизонтів верхнього $\mathrm{T}$ середнього плейстоцену, $\mathrm{T}$ кож у викопних грунт $\mathrm{x} \mathrm{T}$ викопних грунтових комплекс х простежуються зн чно вищі зн чення пок зник пл стичності, які досяг ють 12-16.

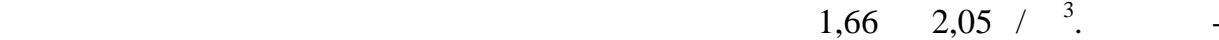

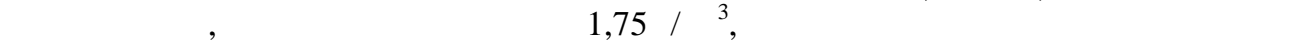
грунт м верхньої ч стини верхніх горизонтів верхнього т середнього плейстоцену.

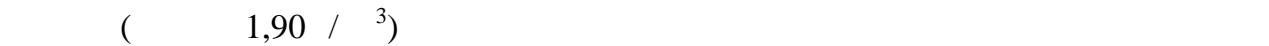
горизонту середньоплейстоценових лесів, породи луцького викопного грунту т верхнього горизонту нижньоплейстоценових лесів.

н чення коефіцієнт пористості досить добре відобр ж ють мікростр тигр фію лесово-грунтової товщі. йвищі з бсолютними пок зник ми коефіцієнти пористості (пон д 0,800$)$ з фіксов но у верхньому т ч стково нижньому підгоризонт х верхнього горизонту верхньоплейстоценових лесів, коршівському викопному грунтовому комплексі. ещо менші $(0,750-0,770)$ зн чення х р ктерні для лесів верхнього горизонту середньоплейстоценових лесів. йнижчі пок зники коефіцієнт пористості $(0,530-0,650)$ вл стиві грунт м луцького викопного грунту т верхнього горизонту нижньоплейстоценових лесів.

рунти м йже всіх виділених стр тигр фічних одиниць м ють низький ступінь вологості, який пересічно не перевищує 0,60 . ише в луцькому викопному грунті т верхньому горизонті нижньоплейстоценових лесів він ст новить пон д 0,90.

ок зники міцності (кут внутрішнього тертя і питоме зчеплення) з г лом досить високі. ерхня ч стин розрізу, як охоплює леси верхнього плейстоцену, м є високі зн чення кут внутрішнього тертя, які досяг ють $30^{\circ}$, т дещо менше $(0,03-0,04)$ питоме зчеплення. оризонти оглеєння i викопні грунти, н вп ки, м ють менші (17-26 $)$ кути внутрішнього тертя і більше $(0,04-0,06$ ) питоме зчеплення. ля відкл дів середнього і нижнього плейстоцену х р ктерні нижчі зн чення як кут внутрішнього тертя (21-27\%), т к і питомого зчеплення $(0,02-0,06 \quad)$.

одуль з г льної деформ ції змінюється в широких меж х. йвищі зн чення (43 ) прит м нні м ловологим, дост тньо щільним лес м верхнього горизонту 
середньоплейстоценових лесів, н йнижчі (10-15 ) - пухким, сильно біогенно переробленим пород м горохівського т коршівського викопних грунтових комплексів.

ловологі, проте дост тньо пухкі леси верхнього горизонту верхньоплейстоценових лесів м ють проміжні зн чення модуля деформ ції, які змінюються від 12-15 до 23

рос дочність грунтів 3 дод ткового тиску 0,3 виявляється фр гмент рно. он вл стив головно н йпухкішим, м ловологим лес м верхнього підгоризонту т верхній ч стині нижнього підгоризонту верхньоплейстоценових лесів. езн чні коефіцієнти прос дочності м ють т кож леси нижнього горизонту верхньоплейстоценових і верхнього горизонту середньоплейстоценових лесів, умусового горизонту горохівського т ілюві льного горизонту луцького викопних грунтових комплексів.

ільні т вологі грунти підгоризонтів оглеєння і соліфлюкції т леси верхнього горизонту нижньоплейстоценових лесів непрос дочні. бсолютні зн чення коефіцієнт прос дочності, з звич й, не перевищують 1-3\%.

д ними вивчення водної витяжки лесово-грунтов п чк пр ктично відмит від легкорозчинних солей. одноч с н тлі з г льного низького вмісту легкорозчинних солей простежується добре вир жен тенденція поступового зменшення їхньої кількості з глибиною. рім того, н д викопними грунт ми з фіксов но незн чне підвищення вмісту легкорозчинних солей.

міст к рбон тів к льцію тісно корелює з мікростр тигр фією. йвищі його зн чення (до $15 \%$ ) є в лесових горизонт х, мінім льні (1-2\%; бо їх зовсім нем ) у викопних грунт х.

н ліз розподілу пок зників скл ду і вл стивостей лесових, п леогрунтових і п леокріогенних горизонтів свідчить про суттєву їхню відмінність, зумовлену особливостями п леогеогр фічних умов їхнього формув ння т ді генетичного перетворення.

1. огуцкий . . нтропогеновые покровные отложения олыно- одолии / . . огуцкий // нтропогеновые отложения кр ины. - иев : ук. думк , 1986. - . 121-132.

2. огуцкий . . сновные п леокриогенные эт пы плейстоцен юго-з п д осточно- вропейской пл тформы / . огуцкий // етвертичный период : методы исследов ния, стр тигр фия и экология. ез. V есоюз. совещ. - ллинн, 1990. $.1 .-.65-66$.

3. огуцький . . есовий покрив олинської височини / . . огуцький, . . огуцький, . . олошин // кр їнське олісся : вчор, сьогодні, 3 втр : зб. н ук. пр ць. - уцьк: дстир'я, 1998. - . 105-107.

4. Fedorowicz S. Loess-paleosol sequence at Korshiv (Ukraine): Chronology based on complementary and parallel dating (TL, OSL), and litho-pedosedimentary analyses / Stanis1aw Fedorowicz, Maria Łanczont, Andryi Bogucki, Jaros1aw Kusiak, Przemys1aw Mroczek, Grzegorz Adamiec, Andrzej Bluszcz, Piotr Moska, Micha1 Tracz // Quaternary International. - 2013. - Vol. 296. - P. 117-130.

m ття: н дійщл до ред кції 14.05.2013

доопр иьов н 17.06 .2013

прийнят до друку 10.10.2013 


\title{
ENGINEERING-GEOLOGICAL CHARACTERISTIC OF THE ROCKS OF THE LOESS-SOIL SERIES FROM THE KEY SECTION AT KORSHIV (VOLHYNIAN UPLAND)
}

\author{
Andriy Bogucki, Petro Voloshyn \\ Ivan Franko National University of Lviv, \\ . Doroshenko Str., 41, UA - 79000 Lviv, Ukraine
}

Korshiv key section is one of the best studied and most complete sections of periglacial loess-soil series of Volhyn-Podillia. There is total thickness of loess-soil series approximately is 30 meters in this section. This key section is stratotype of Korshiv fossil soil complex and Lutsk fossil soil. Pseudomorphs after the structures of cellular ice of several stages of Middle Pleistocene palaeocryogenesis were allocated here for the first time for Volhyn-Podillia.

Detailed description of the section and the results of engineering-geological studies of rocks of all selected loess and palaeosoil horizons were done. Individual properties of selected stratigraphic horizons and their dependence on the paleogeographic conditions of sedimentation were displayed.

Key words: loesses, fossil soils, palaeogeographical conditions, engineering-geological features, subsidence, Volhynian Upland.
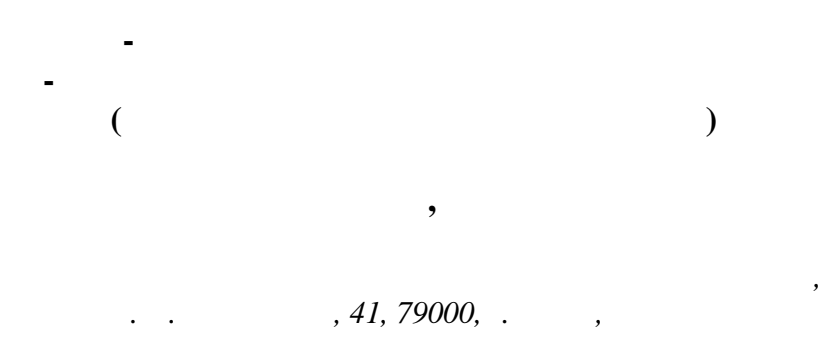

зрез оршев-опорный - один из н иболее хорошо изученных и полных р зрезов перигляци льной лессово-почвенной серии олыно- одолии. бщ я мощность лессово-почвенной серии здесь сост вляет около $30 \mathrm{M}$. то стр тотип коршевского ископ емого почвенного комплекс и луцкой ископ емой почвы. десь впервые для олыно- одолии выделено псевдоморфозы по полигон льно-жильным льд м нескольких эт пов среднеплейстоценового п леокриогенез .

риведено подробное опис ние р зрез, результ ты инженерно-геологического изучения пород всех выделенных лессовых и п леопочвенных горизонтов. ок 3 но индивиду льность свойств выделенных стр тигр фических горизонтов и их з висимость от п леогеогр фических условий ос дон копления.

лючевые слов : лессы, ископ емые почвы, п леогеогр фические условия, инженерногеологические свойств , прос дочность, олынск я возвышенность. 